\title{
STUDY OF ANTIBACTERIAL AND ANTIFUNGAL EFFECT OF THE ESSENTIAL OILS OF CHENOPODIUM AMBROSIOIDES L. AND ROSMARINUS OFFICINALIS L.
}

\author{
MAMMAD ZINEB ${ }^{1 *}$, TORMAL DJASSINRA ${ }^{1}$, KRIBII ABDERAHIM $^{2}$, OUNINE KHADIJA $^{1}$
}

${ }^{1}$ Department of Biology, Health and Environment, Applied Microbiology Team, Faculty of Sciences, University Ibn Tofaïl, BP 133,14000 Kénitra, Morocco. ${ }^{2}$ Department of Chemistry, Laboratory of Separation Processes, Team of Environment and Applied Chemistry, Faculty of Sciences, University Ibn Tofaïl, BP 133, 14000, Kenitra, Morocco. Email: zeinab.yaya@gmail.com

Received: 25 September 2019, Revised and Accepted: 13 November 2019

ABSTRACT

Objective: This work looks at the valuation of two medicinal plants growing wild in the region of Gharb (Chenopodium ambrosioides L. and Rosmarinus officinalis L.) through the study of their antibacterial and antifungal effects vis-à-vis Xanthomonas fragariae, Pseudomonas aeruginosa, Staphylococcus aureus, and two fungal strains; Fusarium solani and Botrytis cinerea.

Methods: The extraction of essential oils from each plant was carried out by hydrodistillation in a Clevenger-type apparatus. The antibacterial and antifungal tests of essential oils are carried out according to the method of diffusion using sterile discs (or aromatograms). Results are expressed in inhibition areas.

Results: Antibacterial activity of essential oil of $R$. officinalis L. is best compared to that of $C$. ambrosioides L. with an area of inhibition that is shared by 1661.06 and 1384.74 , respectively, for bacteria X. fragariae and P. aeruginosa, while this area is between 2122.64 and 2826 mm ${ }^{2}$ for $F$. solani and B. cinerea. Moreover, the essential oils of these two plants by the method of disk diffusion feature a very significant inhibitory effect on $X$. fragariae and P. aeruginosa, whereas they have no effect on S. aureus.

Conclusion: The essential oils of $C$. ambrosioides L. and $R$. officinalis L. could be used as preservatives in food, to protect them from microbial or fungal spoilage.

Keywords: Rosmarinus officinalis L., Chenopodiumam brosioides L., Antimicrobial activity, Antifungal, Essential oil.

(C) 2020 The Authors. Published by Innovare Academic Sciences Pvt Ltd. This is an open access article under the CC BY license (http://creativecommons. org/licenses/by/4. 0/) DOI: http://dx.doi.org/10.22159/ajpcr.2020.v13i1.35875

\section{INTRODUCTION}

Morocco, by its biogeographic position, offers a great ecological and floristic diversity. It is one of the Mediterranean countries that have a long medical tradition and traditional herbal know-how. This natural wealth, however, is opposed by a scarcity of the strategies adopted for its exploitation. The majority of species are still poorly known and largely under-exploited [1]. At present, the traditional use of medicinal plants is still a source of medical care in developing countries [2] and is increasingly important there [3]. According to the World Health Organization, three-quarters of the world's population use traditional medicine and pharmacopeia to cope with health problems [4]. These plants are widely used in traditional medicine by local populations due to their phytotherapeutic properties, particularly in the case of gastrointestinal and respiratory disorders and, as antioxidants, preservatives, and aromas.

Recent studies have shown that essential oils and their constituents have significant potential as antimicrobials and in several industrial and medical fields [5,6]. Rosmarinus officinalis L. is a perennial shrub whose stem, up to $2 \mathrm{~m}$ high, is covered with a greyish bark, it is divided into many opposite and tortuous branches. The narrow leaves are green and shiny on the upper side. The purple-blue flowers, visible from January to May, are grouped at the end of the shoots at the base of the leaves. Chenopodium ambrosioides L. is an upright herbaceous plant, annual, or perennial, with more or less pubescent twig stems and an aromatic smell when pressed [7]. In Morocco, little work has been devoted to the study of the antibacterial and antifungal activity of the essential oils of $C$. ambrosioides L. and R. officinalis L. Thus, this work concerns the valorization of these two plants by studying their antimicrobial activities in relation to four bacterial strains and two fungal strains.

\section{METHODS}

\section{Plant material}

Aerial samples (stems and leaves) of C. ambrosioides L. and R. officinalis L. were purchased and then dried at room temperature $\left(24^{\circ} \mathrm{C}\right)$ for 7 days in the laboratory where the extraction of essential oil was carried out, the preparation of the powder and extracts for the bios tests took place.

Preparation of inoculum and aqueous and ethanolic extracts The inoculum of the strains tested was carried out on four bacterial and two fungal strains whose origin data are presented in Table 1. Near cultures of Pseudomonas aeruginosa MC1 [8], Xanthomonas fragariae [9], $S$. aureus, and in the nutrient broth are incubated at $26^{\circ} \mathrm{C}$ for $24 \mathrm{~h}$. About $6 \mathrm{~mm}$ diameter agar discs of a mushroom culture of at least 7 days are used with a Pasteur pipette. The number of spores is counted using a Hemocytometer under photon microscope and solution 6 must contain about 10 spore/ml [10].

\section{Aqueous extracts}

After drying, the various parts of $C$. ambrosioides L. and R. officinalis L. are crushed using a Moulinex-type crusher to obtain a powder. Fifty grams of each powder are suspended separately in 11 of distilled water. The whole is brought to a boil for $20 \mathrm{~min}$. Then, filtration is carried out on three layers of gas bung. The resulting filtrate is oven dried at $65^{\circ} \mathrm{C}$ to obtain a dry residue. Subsequently, a stock solution of $10 \mathrm{mg} / \mathrm{ml}$ was prepared in sterile distilled water for each plant [11]

\section{Ethanolic extract}

Five grams of powder from each plant were macerated in $100 \mathrm{ml}$ of $99.9 \%$ ethanol for $24 \mathrm{~h}$ in the shade with continuous agitation at room temperature. The extract is filtered and dried at $65^{\circ} \mathrm{C}$ at constant weight [12]. 
Extraction and yield calculation of essential oils

The extraction of the essential oils from each plant was carried out by hydrodistillation in a Clevenger-type apparatus [13]. Three distillations were made by boiling, for $6 \mathrm{~h}, 290 \mathrm{~g}$ of fresh plant material with $1 \mathrm{l}$ of water in a $2 \mathrm{l}$ flask topped by a $60 \mathrm{~cm}$ long column connected to a refrigerant. The water and oil separate by density difference.

The essential oil yield was determined in relation to the dry matter. The essential oil was stored at $4^{\circ} \mathrm{C}$ in the dark in the presence of anhydrous sodium sulfate until its use. The essential oil yield is the ratio between the weight of the oil extracted and the weight of the treated plant. It is expressed as a percentage and calculated by the following formula:

$$
\mathrm{RR}=(\mathrm{Pb} / \mathrm{Pa}) \times 100
$$

$\mathrm{Pb}$ : The weight of the essential oil. Pa: The dry weight of the treated plant.

Antibacterial and antifungal activity of essential oils (direct contact technique)

Antibacterial tests are carried out according to the method reported by Remmal et al. and Satrani et al. $[14,15]$. The essential oil is emulsified by a $0.2 \%$ agar solution to disperse the compounds and improves their contact with the germs tested. Dilutions are prepared in $1 / 10$, $1 / 25,1 / 50,1 / 100,1 / 200,1 / 300$, and $1 / 500$ in this agar solution. In test tubes, each contains $13.5 \mathrm{ml}$ of solid medium Mueller-Hinton for bacteria and potato dextrose agar (PDA) for fungi, $1.5 \mathrm{ml}$ of each dilution is added to obtain the final concentrations of $1 / 100,1 / 250$, $1 / 500,1 / 1000,1 / 2000,1 / 3000$, and $1 / 5000$ (v/v). Then, we shake the tubes before pouring them into Petri dishes. Controls containing the culture medium and the $0.2 \%$ agar solution alone are also prepared.

Table 1: Microbial strains tested and their origin

\begin{tabular}{lll}
\hline Strains tested & Type & Original \\
\hline $\begin{array}{l}\text { Bacteria } \\
\text { Staphylococcus } \\
\text { aureus }\end{array}$ & Gram-positive & Laboratory thesis strain. \\
$\begin{array}{l}\text { Pseudomonas } \\
\text { aeruginosa } \\
\begin{array}{l}\text { Xanthomonas } \\
\text { fragariae }\end{array}\end{array}$ & Gram-negative & Isolated at the Microbiology \\
$\begin{array}{l}\text { Fungi } \\
\text { Botrytis } \\
\text { cinerea }\end{array}$ & & Laboratory, Ibn Tofail \\
$\begin{array}{l}\text { Fusarium } \\
\text { solani }\end{array}$ & - & University \\
\hline
\end{tabular}

Sowing is done by spreading using a Pasteur pipette. The latter is in the form of a nutritious 24-h culture broth for bacteria and in the form of a suspension in the physiological water of spores from a 7-day culture in the PDA for the mushrooms.

Incubation is done at $37^{\circ} \mathrm{C}$ for $24 \mathrm{~h}$ for bacteria and 7 days at $26^{\circ} \mathrm{C}$ for fungi. Reading is done the next day for bacteria and after 7 days for fungi, the boxes considered positive are those with visible colonies.

\section{Dissemination technique by discs (Vincent technique)}

To test the antimicrobial activity of the essential oils of each plant, we used the antibiogram method by diffusion from discs impregnated with pure essential oil. The media cast in Petri dish are seeded with $1 \mathrm{ml}$ of $10^{8} \mathrm{CFU} / \mathrm{ml}$ bacterial suspension for $X$. fragariae bacteria, $P$. aeruginosa, and $S$. aureus, and a sporal suspension of $10^{6} \mathrm{CFU} / \mathrm{ml}$ for Botrytis cinerea and Fusarium solani was prepared. Excess inoculum is removed by aspiration. A volume of $5 \mu \mathrm{l}$ of essential oil is deposited on sterile Whatman paper discs $6 \mathrm{~mm}$ in diameter. In parallel, controls are used to verify the growth of the different strains [16]. The results are expressed as an inhibition area.

\section{Susceptibility of bacterial strains to antibiotics}

The resistance profile of bacterial strains is determined by the Mueller and Hinton medium diffusion method. Antibiotics commonly used in therapy have been retained. The antibiotic discs tested each contain $\mu \mathrm{g}$ : Ampicillin $(10 \mu \mathrm{g})$, tetracycline $(30 \mu \mathrm{g})$, ciprofloxacin cefotaxime (CIP) $(5 \mu \mathrm{g})$, and erythromycin E15 (15 $\mu \mathrm{g})$. Antibiotic discs were applied to Mueller-Hinton medium covered by a 68 inoculum of $10 \mathrm{CFU} / \mathrm{ml}$ for P. aeruginosa and $10 \mathrm{CFU} / \mathrm{ml}$ for $S$. aureus and X. fragariae. After $24 \mathrm{~h}$ of incubation at $37^{\circ} \mathrm{C}$, strain resistance or sensitivity is determined by measuring the diameter of the inhibition zone. Each test is repeated 3 times.

\section{RESULTS AND DISCUSSION}

Average yield of C. ambrosioides L. and Rosmarinus officinalis L. essential oils was about $0.6 \%$ and $1.5 \%$, respectively. Various authors reported variable yields, between $0.8 \%$ and $1.79 \%[16,17]$. This variability in the yields of the essential oils of the two plants can probably be due to the variation of the stage of growth, pedoclimatic conditions, harvest period, harvest time, and drying. Several studies relating to the drying of aromatic and medicinal plants indicate considerable changes, particularly in quantitative terms, in the level of essential oils. However, if a plant is not dried under good conditions, it may degrade and, as a result, lose all its essential oils [18]. In this sense, Benjilali and Zrira found that the content of essential oils in rosemary leaves dried in the shade during a week is 4 times greater than that of the fresh plant [19]. Studies carried out by Silou et al. and Bourkhiss et al. suggest that the increase in the concentration of essential oils expressed as dry matter weight during the $1^{\text {st }}$ days of

Table 2: Antibacterial and antifungal activity of Rosmarinus officinalis L. essential oils

\begin{tabular}{|c|c|c|c|c|c|c|c|c|c|}
\hline $\begin{array}{l}\text { Microorganisms/ } \\
\text { Dilution }\end{array}$ & $1 / 50$ & $1 / 100$ & $1 / 200$ & $1 / 250$ & $1 / 500$ & $1 / 1000$ & $1 / 1200$ & $1 / 3000$ & $1 / 5000$ \\
\hline Pseudomonas aeruginosa & - & - & + & + & + & + & + & + & + \\
\hline Xanthomonas fragariae & + & + & + & + & + & + & + & + & + \\
\hline Staphylococcus aureus & + & + & + & + & + & + & + & + & + \\
\hline Botrytis cinerea & - & - & - & - & - & - & - & + & + \\
\hline Fusarium solani & - & - & - & - & - & - & - & - & + \\
\hline
\end{tabular}

Table 3: Antibacterial and antifungal activity of Chenopodium ambrosioides L. essential oils

\begin{tabular}{|c|c|c|c|c|c|c|c|c|c|}
\hline $\begin{array}{l}\text { Microorganisms/ } \\
\text { Dilution }\end{array}$ & $1 / 50$ & $1 / 100$ & $1 / 200$ & $1 / 250$ & $1 / 500$ & $1 / 1000$ & $1 / 1200$ & $1 / 3000$ & $1 / 5000$ \\
\hline Pseudomonas aeruginosa & - & \pm & + & + & + & + & + & + & + \\
\hline Xanthomonas fragariae & - & + & + & + & + & + & + & + & + \\
\hline Staphylococcus aureus & + & + & + & + & + & + & + & + & + \\
\hline Botrytis cinerea & - & - & - & - & - & - & + & + & + \\
\hline Fusarium solani & - & - & - & - & - & - & - & - & + \\
\hline
\end{tabular}




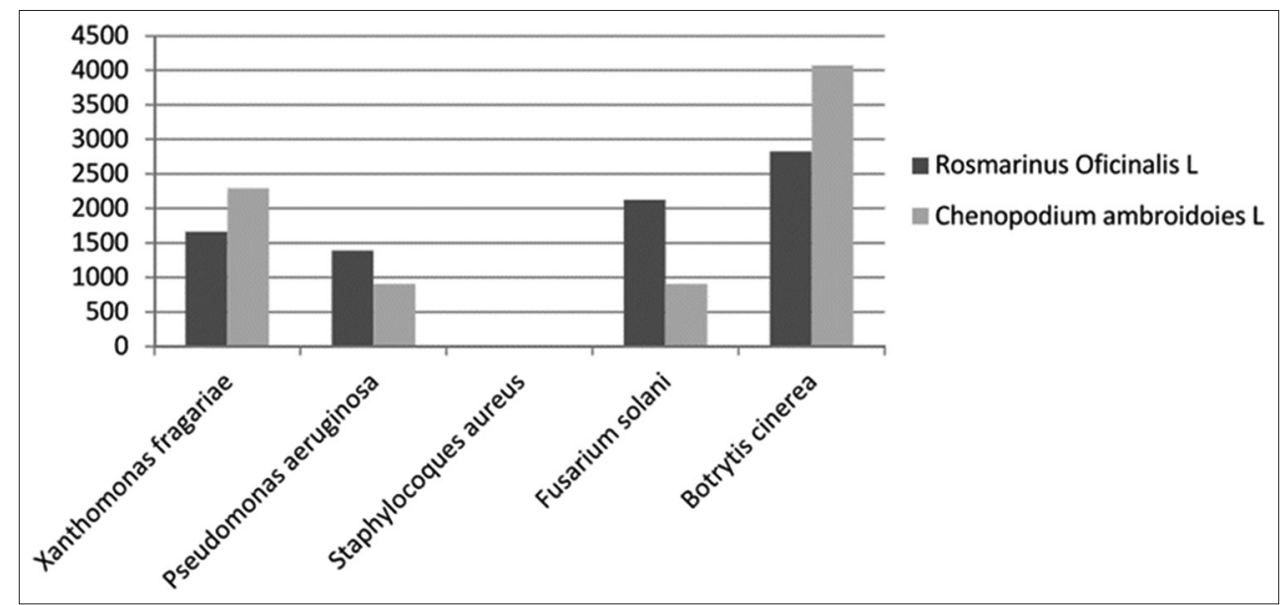

Fig. 1: Result of antibacterial and antifungal activity of essential oil of the two plants of two studied in mm (inhibition area included)

Table 4: Resistance profile of bacterial strains to antibiotics

\begin{tabular}{lllll}
\hline Strains & \multicolumn{2}{l}{ Antibiotic } & & \\
\cline { 2 - 5 } & AMP10 & TE & E15 & CIP \\
\hline Xanthomonas fragariae & $\mathrm{R}$ & $\mathrm{S}$ & $\mathrm{R}$ & $\mathrm{S}$ \\
Pseudomonas aeruginosa & $\mathrm{R}$ & $\mathrm{S}$ & $\mathrm{R}$ & $\mathrm{S}$ \\
Staphylococcus aureus & $\mathrm{S}$ & - & $\mathrm{S}$ & $\mathrm{S}$ \\
\hline
\end{tabular}

E15: Erythromycin, CIP: Cefotaxime, TE: Tetracycline, AMP10: Ampicillin

drying could be explained by physiological activity (enzyme reactions) important. Biosynthesis of essential oils continues and accelerates after harvesting of plant material in response to water stress [20,21].

Tables 2 and 3 show the results of antibacterial and antifungal activity of the essential oils of $C$. ambrosioides $\mathrm{L}$. and $R$. officinalis $\mathrm{L}$. It is noted that the essential oil of $R$. officinalis L. exerted a strong antibacterial activity where the concentration between $1 / 50$ and $1 / 100 \mathrm{v} / \mathrm{v}$ was sufficient to inhibit the growth of $P$. aeruginosa and streptococci, whereas $S$. aureus and $X$. fragariae were resistant. The fungal strains of $F$ solani and B. cinerea were inhibited from $1 / 1200 \mathrm{v} / \mathrm{v}$. with regard to C. ambrosioides L. essential oil: $X$. fragariae and $P$. aeruginosa were more resistant with an inhibition concentration of $1 / 100 \mathrm{v} / \mathrm{v}$. B. cinerea was inhibited from $1 / 1000 \mathrm{v} / \mathrm{v}$, while $F$. solani was inhibited from $1 / 3000 \mathrm{v} / \mathrm{v}$.

Antibacterial and antifungal activity was tested by the aromatogram method on P. aeruginosa, S. aureus, streptococci and X. fragariae, and on $F$. solani and B. cinerea. Fig. 1 shows the results of the effect of each plant's essential oils on the different bacterial and antifungal strains tested.

With the exception of $S$. aureus which is resistant to both essential oils, the other microorganisms show a notable sensitivity. $R$. officinalis $\mathrm{L}$. essential oil inhibition areas range from 1661.06, X. fragariae bacteria and Pseudomonas 1384.74 for two aeruginosa bacteria and range from 2122, 64, and $2826 \mathrm{~mm}$ for $F$. solani and B. cinerea fungi. For the essential oil of $C$. ambrosioides L., the inhibition areas two are 2289.06 and 907.46, mm, respectively, for $X$. fragariae and P. aeruginosa; this area is between 907.46 and $4069.44 \mathrm{~mm}^{2}$ for B. cinerea and F. solani.

These results are consistent with those reported by various authors, who reported high activity of $R$. officinalis L. essential oil on filamentous fungi, protozoa and compare them with bacteria and yeast [22]. On the other hand, various studies on $C$. ambrosioides essential oil have reported antifungal activities on dermatophytes and other filamentous fungi such as Aspergillus, Fusarium, and Colletotrichum [23,24].

The results of antibacterial activity show a sensitivity of $X$. fragariae and $P$. aeruginosa and that $S$. aureus has a very high resistance potential against the antibacterial action of the two essential oils. This action is not surprising because it is carried out on several biocidal agents. This is consistent with a description made by several authors who have described $S$. aureus as a highly resistant bacterial strain, which could explain the absence of the effect of the essential oils of $R$. officinalis $\mathrm{L}$. and C. ambrosioides L. in our study on this bacterium [25].

Differences in the sensitivity of Gram-negative bacteria to two extracts can probably be attributed to the structure and composition of the outer membrane which constitutes an impermeable barrier for many small molecules [26]. Chao et al. explained that these Gram-negative bacteria have a layer of peptidoglycan wedged between the plasma membrane and an external base of lipopolysaccharides and proteins. This structure can prevent the taking of oils or protect the peptidoglycan layer from oils [27]. In vitro sensitivity of strains in the presence of antibiotics is tested by the antibiogram method. Results are rated according to standards (R: Resistant strain, S: Sensitive strain, I: Intermediate strain) [28].

The antibiogram is a test used to perform a resistance profile against various antibiotics and to characterize the interest of studying the sensitivity of antibiotics in assessing the biodiversity of isolated strains. The diameter of the inhibition zone is shown in $\mathrm{mm}$. Table 4 shows the results for the diameters of the inhibition zones obtained.

It is observed that the bacterial strains react differently to the four antibiotics tested, we find that the strains of $X$. fragariae and $P$. aeruginosa have a zone of $<14 \mathrm{~mm}$ which explains their resistance to ampicillin, while the $S$. aureus strain is resistant to this antibiotic.

We note that the strains of $X$. fragariae and $P$. aeruginosa show increased sensitivity to tetracycline with an area $>19 \mathrm{~mm}$, while it has no noticeable effect on $S$. aureus. The strains of $X$. fragariae and $P$. aeruginosa are resistant to erythromycin with an area of $<17 \mathrm{~mm}$, except that $S$. aureus has an increased sensitivity to this antibiotic. Similarly, strains of $X$. fragariae, P. aeruginosa, and $S$. aureus are susceptible to CIP.

\section{CONCLUSION}

This study is the first to provide data on the valorization of essential oils of $C$. ambrosioides $\mathrm{L}$. and $R$. officinalis $\mathrm{L}$. It appears that these two medicinal plants have a strong antibacterial activity and antifungal. C. ambrosioides L. and R. officinalis $\mathrm{L}$. essential oils could be used as preservatives in food products to protect them from microbial or fungal deterioration.

\section{ACKNOWLEDGMENTS}

This work has been made possible through the valuable contributions of many people in our Laboratory of Applied Microbiology and Health. 


\section{AUTHORS' CONTRIBUTIONS}

The authors have contributed to manuscript article preparation and editing.

\section{CONFLICTS OF INTEREST}

We declare that there are no conflicts of interest.

\section{REFERENCES}

1. Salhi S, Fadli M, Zidane L, Douira A. Floristic and ethnobotanical study of medicinal plants in city of Kénitra (Morocco). Lazaroa 2010;31:133-46

2. Tabuti JR, Lye KA, Dhillion SS. Traditional herbal drugs of Bulamogi, Uganda: Plants, use and administration. J Ethnopharmacol 2003;88:19-44.

3. Romero CD, Chopin SF, Buck G, Martinez E, Garcia M, Bixby L. Antibacterial properties of common herbal remedies of the southwest. J Ethnopharmacol 2005;99:253-7.

4. Nedialkov PT, Nikolov SD, Kokanova-Nedialkova Z. The genus Chenopodium: Phytochemistry, ethnopharmacology and pharmacology. Pharmacogn Rev 2009;3:280-306.

5. Başer KH, Demirci B, Demirci F, Koçak S, Akinci C, Malyer H, et al. Composition and antimicrobial activity of the essential oil of Achillea multifida. Planta Med 2002;68:941-3.

6. Dorman HJ, Deans SG. Antimicrobial agents from plants: Antibacterial activity of plant volatile oils. J Appl Microbiol 2000;88:308-16.

7. Cabanis Y, Chabouis L, Chabouis F. Végéteaux et Groupements Végéteaux de Madagascar et des Madagaskareignes. Vol. 4. Tananarive: BDPA; 1969.

8. Bricha S. Study of the Behaviour of Pseudomonas aeruginosa with Regard to Environmental Factors and Decontamination Procedures Applied in the Food Industry. Thesis-faculty of Science, Kénitra, Morocco; 2011. p. 71-152.

9. Djassinra T, Khouidi S, Oulkheir S, Ounine K. Detection de Xanthomonas fragariae au éme niveau des serres de la région du Gharb, proceeding du 8émecongrès de l'association marocaine de protection des plantes-AMPP. November. Rabat; 2012. p. 139-153

10. Ouraïni D, Agoumi A, Ismaïli-Alaoui M, Alaoui K, Cherrah Y, Amrani M, et al. Étude de l'activité des huiles essentielles de plantes aromatiques à propriétés antifongiques sur les différentes étapes du développement des dermatophytes. J Phytothérapie 2005;4:147-57.

11. Ali-Emmanuel N, Moudachirou M, Akakpo AJ, Quetin-Leclercq J. Activités antibactériennes in vitro de Cassia alata, Lantana camara et Mitracarpus scaber sur Dermatophilus congolensis isolé au Bénin. Revue Élev Méd Vét Pays Trop 2002;55:183-7.

12. Iqbal A, Farrukh A, Mohammad O. Modern Phytomedicine. Weinheim: Wiley-VCH Verlag GmbH, Co., KGaA; 2006. pp 384.

13. Clevenger JF. Apparatus for the determination of volatile oil. J Am Pharm Assoc 1928;17:346-51.
14. Remmal A, T-Elaraki A, Bouchikhi T, Rhayour K, Ettayibi M. Improved method for determination of antimicrobial activity of essential oils in agar medium. J Essent Oil Res 1993;5:179-84.

15. Satrani B. Ghanmi $M$, farah A, aafi A, fougrach $H$, bourkhiss B. Composition chimique et activité antimicrobienne de l'huile essentielle de Cladanthus mixtus. Bull Soc Pharm Bordeaux 2008;146:85-96.

16. Atikbekkara F, Bousmaha L, Talebbendiab SA, Boti JB, Casanova J. Chemical composition of the essential oil of Rosmarinus officinalis $\mathrm{L}$ growing spontaneously and cultivated from the Tlemcen. J Biol Health 2007;7:1.

17. Bozin B, Mimica-Dukic N, Samojlik I, Jovin E. Antimicrobial and antioxidant properties of rosemary and sage (Rosmarinus officinalis L. and Salvia officinalis L., Lamiaceae) essential oils. J Agric Food Chem 2007;55:7879-85.

18. Aghfir M, Kouhila M, Jamali A, Mohamed A. Convective Solar Drying for the Conservation of Resmary Leaves (Rosmarinus officinalis). $13^{\text {th }}$ International Days of Thermal Drying. Albi, France; 2007. p. 28-30.

19. Benjilali B, Zrira S. Aromatic and Medicinal Plants. Strengths of the Sector and Requirements for Sustainable Development. Morocco: Hassan II Agricultural and Veterinary Institute Rabat Morocco. 2005.

20. Silou T, Taty-Loumbou F, Chalchat JC. Study of the effect of solar drying on the yield and chemical composition of essential oils extracted from the leaves of Eucalyptus citriodora. Ann Fals Exp Chim 2002;960:287-301.

21. Bourkhiss M, Hnach M, Bourkhiss B, Ouhssine M, Chaouch A, Satrani B. Drying effect on the content and chemical composition of essential oils of Tetraclinis articulata (Vahl) masters. Agrosolutions 2009;20:44-8.

22. Inouye $\mathrm{S}$, Abe $\mathrm{S}$. New approach to anti-infective aromatherapy. Phytotherapy 2007;1:2-4.

23. Kishore N, Chansouria JP, Dubey NK. Antidermatophytic action of the essential oil of Chenopodium ambrosioides and an ointment prepared from it. India Phytother Res 1999;10:453-5.

24. Jardim CM, Jham GN, Dhingra OD, Freire MM. Composition and antifungal activity of the essential oil of the Brazilian Chenopodium ambrosioides L. J Chem Ecol 2008;34:1213-8.

25. Teixeira B, Marques A, Ramos C, Serrano C, Matos O, Neng NR, et al. Chemical composition and bioactivity of different oregano (Origanum vulgare) extracts and essential oil. J Sci Food Agric 2013;93:2707-14.

26. Lambert PA. Cellular impermeability and uptake of biocides and antibiotics in gram-positive bacteria and mycobacteria. J Appl Microbiol 2002;92 Suppl:46S-54S.

27. Chao SC, Young DG, Oberg GJ. Screening for inhibitory actvity of essential oils on selected bacteria, fungi and viruses. J Essent Oil Res 2000;12:639-49.

28. Robin F, Aggoune-Khinache N, Delmas J, Naim M, Bonnet R. Novel VIM metallo-beta-lactamase variant from clinical isolates of Enterobacteriaceae from Algeria. Antimicrob Agents Chemother 2010;54:466-70. 